\title{
Explosive spalling behavior of reactive powder concrete exposed to high temperature
}

\author{
Juan Yang ${ }^{1, a}$, Gai Fei Peng ${ }^{1, b}$ and Guo Shuang Shui ${ }^{1, c}$ \\ ${ }^{1}$ School of civil engineering, Beijing Jiaotong University, China \\ awechico@163.com , bgfpeng@bjtu.edu.cn , ’gsshui@bjtu.edu.cn
}

\section{Keywords: reactive powder concrete, steel fiber, polypropylene fiber, explosive spalling}

Abstract. Explosive spalling behavior of reactive powder concrete (RPC) exposed to high temperature up to $800{ }^{\circ} \mathrm{C}$ and the influence of steel fiber and polypropylene (PP) fiber on it were investigated in this experiment. Results show that RPC specimens encountered severe explosive spalling. However, adding PP fiber can alleviate the explosive spalling of RPC significantly and prevents some specimens from explosive spalling. In addition, the explosive spalling of RPC specimens with the higher moisture content was severe than that of specimens with the lower moisture content.

\section{Introduction}

Reactive powder concrete (RPC) is widely used in many types of structures due to its ultra-high strength and durability. However, the microstructure of RPC is denser than that of high-performance concrete (HPC), their explosive spalling behaviors may be dissimilar. A comparison study [1] on the explosive spalling of RPC and HPC shows that RPC is more likely to encounter explosive spalling than HPC. By observing the microscopic changes on RPC and HPC after exposure to high temperature, Alonso [2] concluded that the resistance to explosive spalling of HPC is better than that of RPC. Therefore, the results on the resistance to explosive spalling of HPC cannot be directly applied to the RPC, of which the explosive spalling behavior needs to be further studied. Many results on the explosive spalling of RPC have been reported. Plain RPC specimens spalled when the temperature was between $260^{\circ} \mathrm{C}$ and $520^{\circ} \mathrm{C}$ [3], but PP fiber significantly improved the resistance to explosive spalling of RPC [4]. Sanchayan [5] also revealed that RPC is highly prone to explosive spalling when the temperature is higher than $400{ }^{\circ} \mathrm{C}$, and PP fibers alleviate the explosive spalling. Liu [6] also reported that RPC specimens spalled at a furnace temperature of $400{ }^{\circ} \mathrm{C}$, and the maximum vapor pressure inside the concrete specimens reached 3.4 MPa. Thus, RPC is highly prone to explosive spalling when exposed to high temperature and the influences need to be further studied.

RPC has the risk of explosive spalling when exposed to high temperature and can reduce fire resistance of concrete elements, even endanger entire structures. Research on the explosive spalling behavior of RPC specimens with different moisture contents was carried out. In addition, the effect of hybrid fibers (steel fiber and PP fiber) on the explosive spalling behavior of RPC was investigated to explore the improvement in alleviating its explosive spalling.

\section{Experiment Details}

Preparation of RPC specimens. Portland cement with the 52.5R strength grade and three kinds of admixtures, including silica fume (SF), fly ash (FA) and ground granulated blast furnace slag (GGBS) were used as binding materials. Artificial sand was used as fine aggregate. The steel fiber used in the specimens is flat-straight copper-coated steel fiber with a length of $16 \mathrm{~mm}$ and a diameter of $0.20 \mathrm{~mm}$, and its tensile strength is $2200 \mathrm{MPa}$. Polypropylene (PP) fiber has a length of $19 \mathrm{~mm}$ and a diameter of $0.15 \mathrm{~mm}$. Super plasticizer ( $50 \%$ solid content) was used.

Two types of RPC were prepared and designated by RPC, RPC-HF, respectively. Their mixture proportions and 56-day compressive strengths are shown in Table 1. All dry materials were added in sequentially and mixed. After all the materials were mixed uniformly, water and water reducing agent 
were added in. The total mixing process lasted 15 minutes. The dimensions of all specimens are 100 $\mathrm{mm} \times 100 \mathrm{~mm} \times 100 \mathrm{~mm}$. After vibration, all of the fresh specimens were immediately plastic-wrapped to minimize moisture loss and then stored at room temperature. After 24 hours of mixing with water, the specimens were demolded and cured in water at $20^{\circ} \mathrm{C}$ for 56 days.

Table 1 Mix proportions and 56-day compressive strengths of RPC

\begin{tabular}{|c|c|c|c|c|c|c|c|c|c|}
\hline \multirow{2}{*}{ Type of concrete } & \multirow{2}{*}{$\mathrm{W} / \mathrm{B}$} & \multicolumn{7}{|c|}{ Quantity $\left[\mathrm{kg} / \mathrm{m}^{3}\right]$} & \multirow{2}{*}{$\begin{array}{l}\text { Compressive } \\
\text { strength }[\mathrm{MPa}]\end{array}$} \\
\hline & & $\mathrm{C}$ & SF & FA & GGBS & FA & Steel fiber & PP fiber & \\
\hline RPC & 0.18 & 540 & 90 & 180 & 90 & 1080 & 78 & 0 & 145.0 \\
\hline RPC-HF & 0.18 & 540 & 90 & 180 & 90 & 1080 & 78 & 1.35 & 145.4 \\
\hline
\end{tabular}

Establishment of moisture content in specimens. Moisture content $\left(w_{m c}\right)$ is defined as the ratio of evaporable water within a specimen at the time of the test to the original amount of evaporable water when initially retrieved from the curing water tank [7]. Specimens used in the test were dried at $105{ }^{\circ} \mathrm{C}$ to yield different moisture contents, i.e. $0 \%, 25 \%, 50 \%, 75 \%$ and $100 \%$. After curing for 56 days, specimens were taken out from the curing water tank and the water on the surfaces of specimens was immediately wiped up. In this case, the moisture content of specimens was considered as $100 \%$ $\left(\mathrm{m}_{1}\right)$. The moisture content was considered as $0 \%$ when the weight $\left(\mathrm{m}_{0}\right)$ of specimens is stable. Using $\mathrm{m}_{0}$ and $\mathrm{m}_{1}$, the target weight $\left(\mathrm{m}_{\mathrm{i}}\right)$ of specimens with any moisture contents can be calculated.

Explosive Spalling Test. Explosive spalling test was conducted on six specimens with the specified moisture content. The specimens were heated in a muffle furnace at a rate of $10.0^{\circ} \mathrm{C} / \mathrm{min}$. The target temperature is $800{ }^{\circ} \mathrm{C}$. When explosive spalling occurred, the corresponding furnace temperature and time were recorded. Additionally, a loud voice can be heard and the total number of the loud voice during heating is recorded as an important parameter used to categorize the degree of explosive spalling.

\section{Results and Discussion}

Temperature range of explosive spalling. Temperatures at which the first and final explosive spalling occurred are defined as the first spalling temperature and final spalling temperature, respectively. Temperature ranges (from the first to final temperature) of the occurrence of explosive spalling of both types of RPC specimens are shown in Table 2. Moisture content significantly affects the first spalling temperature of RPC specimens, as the moisture content increased, the first spalling temperature decreased, i.e. the explosive spalling of the specimens with higher moisture content occurred earlier. This may be attributed to the increased inner vapor pressure in the specimens with higher moisture content [8] and additional temperature gradients induced by water vaporization [9]. The sufficient vapor pressure and thermal stresses resulted from temperature gradients induce explosive spalling.

Table 2 Temperature ranges of the occurrence of explosive spalling of RPC specimens with different moisture contents $\left[{ }^{\circ} \mathrm{C}\right]$

\begin{tabular}{ccccc}
\hline Type of concrete & $w_{m c}=25 \%$ & $w_{m c}=50 \%$ & $w_{m c}=75 \%$ & $w_{m c}=100 \%$ \\
\hline \multirow{2}{*}{ RPC } & $534.7-778.2$ & $432.8-759.0$ & $457.7-764.2$ & $299.9-777.3$ \\
& $(243.5)$ & $(326.2)$ & $(306.5)$ & $(477.4)$ \\
RPC-HF & $478.7-538.6$ & $551.7-669.9$ & $527.1-658.7$ & $387.5-745.7$ \\
& $(59.9)$ & $(118.2)$ & $(131.6)$ & $(358.2)$ \\
\hline
\end{tabular}

Differing with the first spalling temperature, the influence of moisture content in the final spalling temperature of RPC presents no clear trend. During the occurrence of explosive spalling of specimens, released water significantly decreased the temperature in furnace and the released water was controlled by the severity of explosive spaling. However, the occurrence of explosive spalling contains uncertainty and randomness, resulting in the unclear trend of the final spalling.

Compared with the explosive spalling of RPC incorporated only steel fiber, the addition of steel fiber and PP fiber significantly reduce the range temperature of the occurrence of explosive spalling, 
and the resistance to explosive spalling of RPC specimens with hybrid fiber was much better than that of RPC with only steel fiber. Thus, PP fiber can be a great factor in improving the resistance to explosive spalling of RPC specimens.

Number of loud voice and duration of explosive spalling. Numbers of loud voice and duration of explosive spalling occurrence of RPC specimens are listed in Table 3. The more the numbers of loud voices or the longer the duration of occurrence of explosive spalling is, the severer the explosive spalling of concrete specimens is. Results indicate that the resistance to explosive spalling of RPC specimens with hybrid fiber was much higher than that of RPC specimens with only steel fiber. As like the temperature range of the occurrence of explosive spalling, the number of loud voice and duration of explosive spalling can be also regarded as a critical parameter for evaluating the severity of explosive spalling of RPC. In addition, as the moisture content increases, the number of loud voice and the duration of explosive spalling increase.

Table 3 Number of loud voice and duration of explosive spalling of concrete specimens with different moisture contents

\begin{tabular}{|c|c|c|c|c|c|c|c|c|}
\hline \multirow{2}{*}{ Type of concrete } & \multicolumn{4}{|c|}{ Number of loud voice [times] } & \multicolumn{4}{|c|}{ Duration [minute] } \\
\hline & $\begin{array}{l}w_{m c}= \\
25 \%\end{array}$ & $\begin{array}{l}w_{m c}= \\
50 \%\end{array}$ & $\begin{array}{l}w_{m c}= \\
75 \%\end{array}$ & $\begin{array}{c}w_{m c}= \\
100 \%\end{array}$ & $\begin{array}{l}w_{m c}= \\
25 \%\end{array}$ & $\begin{array}{l}w_{m c}= \\
50 \%\end{array}$ & $\begin{array}{l}w_{m c}= \\
75 \%\end{array}$ & $\begin{array}{c}w_{m c}= \\
100 \%\end{array}$ \\
\hline RPC & 35 & 38 & 137 & 207 & 49 & 50 & 52 & 72 \\
\hline RPC-HF & 6 & 30 & 35 & 93 & 14 & 26 & 46 & 80 \\
\hline
\end{tabular}

Compared with steel fiber reinforced RPC specimens, the number of loud voice of explosive spalling of hybrid fiber reinforced RPC specimens was much less, and their duration of explosive spalling was much shorter. It can be concluded that the positive effect of hybrid fibers on improving the resistance to explosive spalling of RPC is more significant than that of steel fiber. This is because PP fibers melt at about $170{ }^{\circ} \mathrm{C}$ and create channels for vapor pressure to escape. However, when the moisture content was $100 \%$, the duration of explosive spalling of hybrid fiber reinforced RPC was slightly longer than that of RPC with only steel fiber.

Morphology of the specimens after explosive spalling test. All the specimens with the $0 \%$ moisture content did not encounter explosive spalling, but many small cracks were observed in the RPC specimens. Specimens with the moisture contents ranging from $25 \%$ to $100 \%$ experienced explosive spalling with different severity, as shown in Table 8.

Table 4 Appearance of specimens after explosive spalling occurred

\begin{tabular}{|c|c|c|c|c|c|}
\hline \multirow{2}{*}{ Type of concrete } & \multicolumn{5}{|c|}{ Moisture contents } \\
\hline & $0 \%$ & $25 \%$ & $50 \%$ & $75 \%$ & $100 \%$ \\
\hline RPC & & & & & \\
\hline RPC-HF & & & & & \\
\hline
\end{tabular}

For steel fiber reinforced RPC specimens with the moisture content of $25 \%$, only several small blocks on the top part peeled off or the tops of the specimens experienced explosive spalling while the rest of the specimens retained their integrity. When the moisture content is above $50 \%$, all of the specimens spalled into small pieces, the severity degree of explosive spalling increases as the moisture content increases. However, the addition of hybrid fiber significantly alleviates the explosive spalling of RPC specimens if their moisture contents are not above $75 \%$.

The explosive spalling of RPC specimens with $100 \%$ moisture content is extremely serious, and incorporation of hybrid fiber did not improve it obviously. The reason may be that the high vapor pressure yields quickly and cannot be released in time through the way created by melted PP fibers. This suggests that PP fiber may not be effective in improving the explosive spalling resistance of RPC when the specimens contain saturated water. Of course, the dosage of PP fibers is an important factor and needs further research. 


\section{Conclusions}

Based on the experimental research on the explosive spalling behavior of reactive powder concrete exposed to high temperature up to $800^{\circ} \mathrm{C}$, the results can be concluded as follows.

(1) Steel fiber reinforced RPC specimens seriously spalled while hybrid fiber alleviates the explosive spalling significantly, because after the PP fibers melted, a large number of channels formed and released the vapor pressure in time.

(2) Moisture content significantly affects the explosive spalling of RPC. The higher the moisture content is, the more serious the explosive spalling is. This indicates that vapor pressure is the main factor that causes the explosive spalling of UHPC.

\section{Acknowledgements}

The authors gratefully acknowledge the financial support of the National Science Foundation of China (Project No. 51278048, 50978026), and the Fundamental Research Funds for the Central Universities of China (Project No: 2011YJS293).

\section{References}

[1] E. W. Klingsch, A. Frangi, M. Fontana. High- and ultrahigh-performance concrete: A systematic experimental analysis on spalling [J]. ACI Special Publication, 2011.

[2] C. Alonso, C. Andrade, E. Menendez, and E. Gayo. Microstructural Changes in High and Ultra High Strength Concrete Exposed to High Temperature Environments. Proceedings of the 4th International Conference Quality of Concrete Structures and Recent Advances in Concrete Materials and Testing. ACI Special Publication 229, SP 229-19, 289-302, Olinda, PE, Brazil, September 2-7.

[3] M. Behloul, G. Chanvillard, P. Casanova, et al. Fire resistance of ductal ultra-high performance concrete $[\mathrm{C}]$. Proceedings of the first fib conference-development of new materials, Session 7, 421-430.

[4] W. Z. Zheng, B. F. Luo, Y. Wang. Compressive and tensile properties of reactive powder concrete with steel fibers at elevated temperatures $[\mathrm{J}]$. Construction and Building Materials, 41 (2013), 844-851.

[5] S. Sanchayan, N. Gowripalan, J. Foster S. Mechanical properties of fibre reinforced reactive powder concrete after exposure to high temperatures [C]. From materials to structures: advancement through innovation-Samali, Attard \& Song (Eds), 2013 Taylor \& Francis Group, London, ISBN 978-0-415-63318-5, 1177-1181.

[6] H. B. Liu. Experimental study on the mechanical properties and explosive spalling of reactive powder concrete exposed to high temperature [D]. China University of Mining \& Technology, Beijing, Doctoral dissertation, 2012.

[7] G. F. Peng, J. Yang, Y. X. Shi, et al. Experimental study of explosive spalling resistance of ultra-high-performance concrete [J]. Journal of Building Materials, 2017, 20(2): 229-233.

[8] Mindeguia J. C., Pimienta P., Hager I., et al. Influence of water content on gas pore pressure in concretes at high temperature [C]//International Rilem Workshop on Concrete Spalling Due to Fire Exposure. 2011.

[9] J. C. Mindeguia, P. Pimienta, A. Noumowé, et al. Temperature, pore pressure and mass variation of concrete subjected to high temperature-experimental and numerical discussion on spalling risk [J]. Cement and Concrete Research, 40 (2010): 477-487. 